\title{
The Promotion of Regional Economic Cooperation to the Process of the Marketization of the National Economy
}

\author{
Jun GAO ${ }^{1, \text { a }}$, He ping $\mathrm{GUO}^{2}$ \\ ${ }^{1}$ Changchun university of technology, Changchun 130012, China, \\ ${ }^{2}$ Vocational and Technical College of Da Lian Ocean University, DaLian 130012,China \\ a,gaojun2013@yeah.net
}

Keywords: Regional economic cooperation; Economic marketization; Investment income model; GDP weighted Gene coefficient; Tell index

\begin{abstract}
Due to the influence of historical and regional complex factors, China's national economy and regional development are not balanced. In order to speed up the process of marketization of China's national economy, it must strengthen regional economic cooperation; synthetically plan the regional economic development to speed up the economic development of regional marketization. Based on this, the paper further analyzes and studies the impact of regional economic cooperation on the process of the marketization of China national economic.
\end{abstract}

\section{Introduction}

The imbalance of regional economic development will affect the overall development of the national economy. The marketization level is an important index to measure the economic development.

\section{Analysis on the study of Chinese regional economy and the characteristics of marketization}

The development of China's regional economy presents a long-term imbalance development trend, which has both historical factors and geographic resources factors [1]. Of course, it is also related with the international development policy strategy and the subjective system. Geographic resources factors are the irreversible development factors, but the subjective factors can be changed China's economy is on the path of marketization development. The imbalance of regional economic development has seriously affected the overall level of China's market economy. Therefore, it may reform the regional economic development in the economic policy system. Firstly, it can analyze the characteristics of Chinese regional economy from the level of the marketization and China's eastern and western market economy development [2,3]. After China's accession to the WTO, the degree of opening up is increasingly high, and regional economic differentiation is more and more obvious, which makes the open area be more open, and the backward area be more backward.

It is the dynamic trend of China's marketization level with time changes. It can be seen from the chart, along with the time passed, China's industrialization level has become more and more obvious [4]. Industrialization also has been contributed to the development level of the marketization, but with the increased open degree of reform and opening up, the development of the third industry has promoted the development of Chinese marketization too. There is a difference between the level of industrialization and marketization level which gradually presents a narrowing trend, but China's economy wants to go the path of marketization economy, it must firstly construct industrialized nation to improve the level of industrialization. It has reflected the common per capita GDP weighted Gene coefficient and Tell index of regional economic disparities. It can be seen from the chart, China economic regional absolute disparity is on the rise [5]. 
The marketization growth rate of regional economy appears regional unbalanced development trend. Eastern region is much higher than the average level of growth, and western region is significantly lower than the national average level. This article through the literature research, makes score statistics on the marketization level of each region. The score result is as shown in Table 1.

Table 1. Marketization index average score

\begin{tabular}{c|c|c|c|c|c}
\hline Regionl & $\begin{array}{c}\text { Government } \\
\text { intervention in } \\
\text { the market }\end{array}$ & $\begin{array}{c}\text { The development } \\
\text { degree of the non } \\
\text { state-owned } \\
\text { economy }\end{array}$ & $\begin{array}{c}\text { The degree of } \\
\text { market-oriented } \\
\text { products }\end{array}$ & $\begin{array}{c}\text { Market } \\
\text { Elements market } \\
\text { degree }\end{array}$ & $\begin{array}{c}\text { intermediaries } \\
\text { and legal } \\
\text { protection }\end{array}$ \\
\hline $\begin{array}{c}\text { West Area } \\
\text { Middle area }\end{array}$ & 7.3 & 7.2 & 8.5 & 5.4 & 6.1 \\
$\begin{array}{c}\text { East Area } \\
\text { The difference } \\
\text { between East and } \\
\text { West }\end{array}$ & 4.7 & 3.3 & 6.1 & 2.8 & 4.7 \\
$\begin{array}{c}\text { The difference } \\
\text { between East and } \\
\text { Middle }\end{array}$ & 3.1 & 3.7 & 2.4 & 3.2 & 2.1 \\
\hline
\end{tabular}

From Table 1, it can be seen that the difference of the level of marketization between East and West of is the biggest. Differences of the development degree of non-state-owned economy have reached 3.7. The lowest marketization differences is the market intermediaries and legal protection, and the difference is 2 .

\section{The mathematical model of regional economic cooperation reform}

The development of the regional economy belongs to the multi-stage and trans-regional investment means. This paper mainly through the economic growth way establishes the mathematical model of regional economy marketization overall development. Firstly, assuming that $y_{i}(i=0,1, \cdots, k-1)$ represents the investment of state key construction projects in different areas. $x_{g}^{j}(g=0,1, \cdots, k-1 ; j=1,2, \cdots, n)$ represents the investment amount of the key project for investors in the region $g . z_{g}^{j}(g=0,1, \cdots, k-1 ; j=1,2, \cdots, n)$ represents the initial stage investment amount of the key project in the region $g$. When it is $z_{g}^{j}<0$, it represents the project capital out flowed. When it is $z_{g}^{j}<0$, it represents the project capital inflowed. $H_{g}^{j}(g=0,1, \cdots, k-1 ; j=1,2, \cdots, n)$ represents the process rate of marketization in region $g$, and it is set as a fuzzy variable [15]. $\beta$ is the market return, and $\delta$ is the market process transaction cost.

Based on the above assumptions, the fuzzy system equation of marketization process can be established.

$$
\left\{\begin{array}{l}
y_{g+1}=(1+\beta)\left[y_{g}-\sum_{j=1}^{n}\left(H_{g}^{j}+\delta\left|H_{g}^{j}\right|\right)\right] \\
x_{g+1}^{j}=\left(1+z_{g}^{j}\right)\left(x_{g}^{j}+\theta_{g}^{j}\right),
\end{array} \quad j=1,2, \ldots, n\right.
$$

Constraints can be represented by the formula.

$$
\begin{aligned}
& x_{g}^{j} \geq 0 \\
& y_{g} \geq 0 \\
& -x_{g}{ }^{j} \leq z_{g}^{j} \leq y_{g}
\end{aligned}
$$

Assuming that the regional investment mathematical model is represented by the formula (3). 


$$
\left\{\left[\frac{y_{g+1}+\sum_{j=1}^{n} x_{g+1}^{j}-\left(y_{g}+\sum_{j=1}^{n} x_{g}{ }^{j}\right)}{y_{k}+\sum_{j=1}^{n} x_{g}^{j}}\right] \leq R\right\}, g=0,1, \ldots, K-1
$$

Assuming the probability that can promote the development of regional economic marketization is:

$$
\operatorname{Cr}\left\{\left[\frac{y_{g+1}+\sum_{j=1}^{n} x_{g+1}^{j}-\left(y_{g}+\sum_{j=1}^{n} x_{g}{ }^{j}\right)}{y_{k}+\sum_{j=1}^{n} x_{g}^{j}}\right] \leq R\right\} \leq \beta
$$

In order to make the market objective expectation be maximum, mathematical model can be written as:

$$
\begin{cases}\max & E\left[y_{K}+\sum_{j=1}^{n} x_{K}^{j}\right] \\ \text { s.t. } & \\ & y_{g+1}=(1+\beta)\left[y_{g}-\sum_{j=1}^{n}\left(z_{g}^{j}+\delta\left|z_{g}^{j}\right|\right)\right] \\ & x_{g+1}^{j}=\left(1+H_{g}^{j}\right)\left(x_{g}^{j}+z_{g}{ }^{j}\right), j=1,2, \ldots, n \\ & \operatorname{Cr}\left\{\left[\frac{y_{g+1}+\sum_{j=1}^{n} x_{g+1}^{j}-\left(y_{g}+\sum_{j=1}^{n} x_{g}{ }^{j}\right)}{y_{k}+\sum_{j=1}^{n} x_{g}^{j}}\right] \leq R\right\} \leq \beta \\ & -x_{g}^{j} \leq z_{g}^{j} \leq x_{g}, y_{g} \geq 0, x_{g}^{j} \geq 0, g=0,1, \ldots, K-1, j=1,2, \ldots, n\end{cases}
$$

\begin{tabular}{|c|c|c|c|c|c|}
\hline Regionl & $\begin{array}{l}\text { Government } \\
\text { intervention in } \\
\text { the market }\end{array}$ & $\begin{array}{l}\text { The development } \\
\text { degree of the non } \\
\text { state-owned } \\
\text { economy }\end{array}$ & $\begin{array}{c}\text { The degree of } \\
\text { market-oriented } \\
\text { products }\end{array}$ & $\begin{array}{c}\text { Elements market } \\
\text { degree }\end{array}$ & $\begin{array}{c}\text { Market } \\
\text { intermediaries } \\
\text { and legal } \\
\text { protection }\end{array}$ \\
\hline West Area & 6.2 & 7.5 & 7.1 & 5.2 & 5.8 \\
\hline Middle area & 5.9 & 7.2 & 6.8 & 5.0 & 5.3 \\
\hline East Area & 5.6 & 7.1 & 6.5 & 5.1 & 5.5 \\
\hline $\begin{array}{c}\text { The difference } \\
\text { between East and } \\
\text { West }\end{array}$ & 0.6 & 0.4 & 0.6 & 0.1 & 0.3 \\
\hline $\begin{array}{c}\text { The difference } \\
\text { between East and } \\
\text { Middle }\end{array}$ & 0.3 & 0.3 & 0.3 & 0.2 & 0.5 \\
\hline
\end{tabular}

\section{Study on the promotion effect of regional economic cooperation on marketization}

According to the mathematical model of the second parts, the paper through the method of economic models accounting makes different regional invest balanced funds for projects, and then it reviews the marketization development level in the east, central $d$ weat areas in China. The paper obtains a series of results.

Table 2. Marketization index average score

It can be seen from Table 2 that differences of marketzationi level between eastern, middle and western has decreased obviously, and the differences of factor markets have reduced to 0.1 , which makes the market development level of Eastern and Western keep up with each other. The biggest difference of market development progress is 0.6. In Table 2, it shows the promotion effect of regional economic cooperation on marketization is obvious. 


\section{Conclusions}

In this paper, it combined marketization index level score with per capita GDP weighted Gene coefficient and Tell index to make thorough research on the level of marketization of China's national economy, and the promotion role of the regional economic cooperation on the marketization. In the first part of this paper, it made a detailed analysis the characteristics of China's regional economic and China's marketization economic development. Through the analysis, it found that China's regional economic development was imbalance, and the eastern region market level was much higher than the western region. In the second part of this paper, it introduced the mathematical model of regional key project investment income, and combined with the characteristics of eastern and western to make equilibrium investment in the eastern and western regions, which obtained the marketization score table of regional economic development and the schematic diagram of difference between regional economic development speed and the areas. Marketization score table showed that after a key project investment, the minimum difference of regional marketization score was narrowed to 0.1, which was smaller than the previous 2.0, and the economic market development speed also showed equilibrium situation.

\section{References}

[1] Tatyana A. Koreshkova, "A quantitative analysis of inflation as a tax on the underground economy", Journal of Monetary Economics, Vol. 53, No. 4, pp. 773-796, 2006.

[2] George K. Davis, David Hineline, Bryce E. Kanago, "Inflation and real sectoral output shares: Dynamic panel model evidence from seven OECD countries", Journal of Macroeconomics, Vol. 35, No. 4, pp. 607-619, 2011.

[3] Zhisheng Sun, "Research on Enterprise Strategic Cooperation with the Background of Regional Economic Integration Taking the Enterprise Cooperation in Supply Chain as an example ", IJACT, Vol. 4, No. 12, pp. 336 - 342, 2012.

[4] Michael Bruno, William Easterly, "Inflation crises and long-run growth", Journal of Macroeconomics, Vol. 41, No. 1, pp. 3-26, 2010.

[5] Shu Huan, Yan Yufan, "The Study on the Expansion Orientation and the Development Strategy between Coastal Ports of Jiangsu and their Hinterlands with the Cooperation of Jiangsu and Taiwan in China", AISS, Vol. 5, No. 2, pp. 223 - 230, 2013. 